\title{
Research on Development of Reading-Writing Integration in Chinese EFL College Education
}

\author{
Zhitong Wang*
}

College of Foreign Languages, Zhejiang University of Technology, Hangzhou 310012, China
${ }^{*}$ Corresponding author email: 201906010307@ zjut.edu.cn

\begin{abstract}
Based on the review of the studies on the relationship between reading and writing and how reading-writing integration pedagogy was created, the author did a research on the development of reading-writing integration in Chinese English-as-a-Foreign-Language (EFL) college education. Along with a short interview and small-range survey of the teacher and students from the College of Foreign Languages in Zhejiang University of Technology. The study showed that reading ability and writing performance had a significant relation and it suggested reading-writing integration pedagogy is useful and effective under the basic national conditions of Chinese advanced foreign language education.
\end{abstract}

Keywords: relationship between reading and writing, reading-writing integration, EFL, college education

\section{INTRODUCTION}

In the last few decades, researchers have been studying the relationship between reading and writing. This part will introduce the definition of reading-writing integration and how the whole essay is organized.

\subsection{Definition of Reading-Writing Integration(RWI)}

Reading-writing integration (RWI) refers to teaching reading through writing or teaching writing through reading. Compared with teaching reading or writing separately, it is a combined method of teaching reading and writing. Generally, it is thought to be an English writing instruction in Chinese college.

\subsection{Paper Structure}

This paper is designed to examine the development of RWI in Chinese English-as-a-foreign-language (EFL) education, with an aim to study relationship between reading and writing and to investigate the development of RWI instruction in Chinese college EFL education.

The literature review part is divided into two sections. A brief summary of the development and current situation of Chinese EFL writing education is discussed in the first section. An investigation of relationship between English reading and writing as L1 and L2 is showed in the second section. With an examination of the aforementioned contents, the body part smoothly demonstrates how RWI instruction originated and developed through years in China and other countries.

Before reaching the conclusion, the author presents a report on her short interview and small-range survey on teacher and students from English major of College of Foreign Languages (CFL) in Zhejiang University of Technology (ZJUT). The author hopes to present how teacher and students view on RWI pedagogy and gives her views on it, with the expectation to offer suggestion for future research in this field and to make a positive contribution to the reformation of Chinese EFL writing education.

\section{LITERATURE REVIEW}

\subsection{Summary of Chinese EFL Writing Education}

Since 1980s, correlational researches on Chinese English writing has been increasing [1]. Many scholars has devoted to studying several issues in the field of Chinese EFL writing. Education of college English writing for EFL learners has also been one of the most widely examined topics.

The reform of Chinese EFL writing education is never stopping. Different teaching methods bring different outcomes. Teachers in Chinese colleges strived 
to search for effective ways to teach writing. Researches on Second Language Acquisition (SLA) has led to many innovative education notions and methodologies. Chinese EFL writing education is different from either Chinese writing education or English writing education in English-speaking countries. A comparative study showed that most English teachers in Chinese colleges chose "product approaches" as their basic method to teach English writing [30]. "Product approaches" usually organizes students to imitate, transcribe and revise sentences. It is defined as a "bottom-up" teaching methodology, a writing built on sentences [31]. A linear teaching course (outline-writing-editing) plays a role in "product approaches", because what matters to both teacher and student is the product of writing. Little communicative process or curriculum activities are included in class conducted by "product approaches". This method is apt to be used in model instruction, based on constructivism. Many teachers have applied model instruction into their writing lessons and they have indicated that model instruction was thought to be the best way to integrate reading teaching methods with writing teaching methods because it seemed to be pertinent and instructive [6]. Compare to "product approaches", "process approaches" is thought to be the "top-down" methodology in teaching English writing. Instead of exhibiting the one-off linear behavior like "product approaches", "process approaches" is a generative process which contains recurrent activities including "thinking--writing--revising--re-thinking--..." [32] Obviously, this approach focuses more on the interactive behaviors between teachers and students, offering more opportunities for them to discuss and analyze texts and compositions students wrote. Since the China basic national conditions of foreign language education is proposed, studies on composing processes of advanced EFL learners are being undertaken more seriously. "Process approaches" tackles with the issue that time and feedback are two key elements in English writing lessons [33]. In the process of composition, students generate ideas, synthesize them in sentences and compose a writing, with the help of teachers, then refine and edit their texts. By continually revising and communicating with mentors, students grasp the importance of the composing process apart from the result itself. Thus, it seems "process approaches" is more in line with the rules of SLA and has been proven to be effective in practice [32].

Despite a large existence of teaching EFL writing by "product approaches" because of the needs of the examination-oriented education situation, there appears to be some young teachers carrying out "communicative approaches" in their EFL education for advanced learners. Various methods and curriculum activities are applied in teaching English writing by "communicative approaches". For example, teachers set a theme for students to freewrite. Freewriting is defined by Martinez as "unstructured writing or 'thinking' on paper" [34]. Students write down their thoughts and teachers review it, give grammatical or lexical advice and complementary opinions and let students expand on them. This is what Martinez called "Round Robin" practice [34]. Discussion, or precisely, brainstorming, is another often-used method in revising stage. By brainstorming, students could acquire revising ability and gain benefits from others' opinions.

Inspired by "listening speaking reading writing" (LSRW) instruction, some teachers tend to combine reading and writing together into their education process. The understanding and application of language is realized during the process of repeatedly reading and writing [30]. The "learn together, use together" (LTUT) principle suggests that "the structure of a foreign language must be learned in an appropriate linguistic environment" [35]. People comprehend the meaning of linguistic structures in order to convey and communicate ideas by languages. LTUT rules emphasized the linkage and integration of relevant variables in the process of learning a foreign language [35], which indicated reciprocal actions were important during EFL learning. Vygotsky's statement on the relationship between interaction and language acquisition is a strong support for "communicative approaches". He stated that "Interaction is the source of all knowledge and skills learned by humans." [36] The concept of learning by interaction explains the basic laws of language acquisition. The notion further influences the movement of EFL writing education in China.

\subsection{Relationship between Reading and Writing}

\subsubsection{Relationship between Reading and Writing as First Language(L1)}

One of the oldest and the most comprehensive investigations of the relationship between reading and writing was conducted by Loban. He discovered a high relation between reading achievement and writing ability in the upper elementary students and also concluded that this relation became stronger when the grades went higher. Just as what Loban had put forward--"those who read well also write well; those who read poorly also write poorly" [12], there exists a high correlation between reading ability and writing ability. A large body of studies has been devoted to investigating whether reading and writing have fairly relations between each other. In Lazdowski's study, he connected the reading scores of 338 students in Grades 7-13 with their writing scores and predicted that "proficiency in writing ability indicated a relative degree of proficiency of reading" [38]. Tieney and Shanahan examined the connection between reading and 
writing using "shared knowledge" method [19]. Their results showed that reading and writing were $25 \%$ to $50 \%$ overlapped between each other, which further suggested that they were based on the similar cognitive structures and there underlay mutual cognitive strategies between reading and writing [19]. In other words, reading and writing are considered literacy skills which have complementary roles [29].

Despite the fact that these aforementioned studies have statistically found the unanimously positive relation between reading and writing by holistic scoring in assessment of students' writing performance, questionable issues still remain. For example, whether the writing abilities were measured accurately, whether the quantity of participants was large enough to be trustful, whether there were L2 learners included in the test subjects. Such questions indicate that it is necessary to take relationships between reading and writing in L2 into consideration and to conduct researches on them.

\subsubsection{Relationship between Reading and Writing as Second Language(L2)}

Regardless of the limitations in the previously mentioned studies, the significant relationship between reading and writing is well recognized by scholars. However, the relationship between reading and writing for L2 learners is generally expected to be different from that for L1 learners. A study by Hedgcock and Atkinson revealed that L1 and L2 learners appeared different when it came to the influence of extensive reading on their writing skills [28]. In fact, considering reasons such as cultural backgrounds, cross-linguistic characteristic of L2 learners [26], L1 language skills, L2 proficiency, reading experience and so on [27], relationship between reading and writing in L2 learning creates more rooms for scholars to do research on. Several correlational studies have unveiled possible variables in relationship between reading and writing abilities of L2 learners abroad. For instance, a number of scholars have investigated the role of L2 proficiency in the relationship between reading and writing abilities. Llach followed primary school Spanish EFL learners with low to low-intermediate English proficiency and measured their reading and writing abilities. The research results showed no significant connection between reading and writing abilities of low proficiency primary L2 leaners, but a notable relation did existed within the group of low-intermediate proficiency L2 leaners [29]. Jihye Choi et al. statistically showed a close relationship between reading comprehension ability and writing performance of advanced Korean EFL leaners when learners' L2 proficiency is taken into account [37]. Thus, it seems L2 proficiency has an influence on relationship between reading and writing abilities of L2 leaners from different levels.
Inspired by foreign scholars' opinions on the relationship between reading and writing, Chinese scholars have also drawn several correlational conclusions about it. Chen Liping concluded that reading and writing are two similar, dynamic and interactive processes, which means they both involve pre-existing memory structures, analyse discourse structures, and have both comprehension and composition behaviours [6]. Xie Weina also concluded that reading and writing have indivisible relationships, in which reading and writing are two actions that imitate each other [5]. When students are reading, they tend to guess the intentions of the writer, put themselves in writer's shoes and understand writer's thoughts. Understanding what, how and why the author wrote the article seems to be a part of learning how to write [5]. Thus, many scholars including Xie Weina suggested that RWI be applied into Chinese EFL teaching.

\section{DEVELOPMENT OF READING- WRITING INTEGRATION}

\subsection{Development of Reading-Writing Integration Abroad}

Before the 1980s, many foreign scholars had already discussed about the relationship between reading and writing and put forward the integration of writing and reading (RWI) as a new way to teach English writing. H.G. Widdowson pointed out that English learners should learn reading skills by learning how to write and improve writing skills by learning how to read [2]. According to the input and output hypothesis, reading and writing are relatively two core concepts in the way of inputting and outputting messages and ideas [3]. The abilities of reading and writing tend to have a positive relation, which means that people who are better at reading tend to be better at writing, and vice versa [4].

Mills conducted a four-year longitudinal study on two groups of fourth grade children to find the effects of children's literature on teaching composition. His study results showed that children from the experimental group which had reading or listening to children's literature added into teaching composition scored profoundly higher than the control group without children's literature part [39]. Bossone and Quitman reported significant effects on students' expository writing by correlating reading instruction with writing instruction in their study involving 71 teachers and more than 2000 high school and beginning college students [40]. In a correlational and recent study, some scholars examined the effectiveness extensive reading could have on English writing performance, and their study showed that extensive reading can help EFL learners achieve significant gains and sizeable effects during their writing study [9]. What's more, the method also 
had received positive responses from the EFL learners [9].

Blanton designed a whole language (WL) approach to integrate reading task with writing task. Throughout the whole procedure, he assigned students to write journals according to the comprehension questions after reading the texts, then divided students into small groups for further discussion based on the texts and journals. Blanton reported that unlike the skills approach, WL approach was thought to be more beneficial for EFL college students because they not only learnt the content or language of the texts, they also absorbed knowledge during the course of reading and writing [41]. Students began to create with what they have learnt from the author and with what they have gained through the peer discussion.

After the 1990s, more scholars became unanimously aware of the strong effects integrating reading into writing instruction. "Through careful and accurate assessment, design and teaching, teachers can help students understand the relationship between reading and writing. Once the students understand it, teachers can teach students how to improve reading skills by improving writing ability, and vice versa." [23] The famous curriculum designer Mermelstein intended that a powerful community of learners should be created. In curriculum design, she suggested literacy-skill integrity be realised by teaching reader's and writer's thinking patterns and students' literacy skills be developed by analysing composition case written by students.[22] By model instruction, students could comprehend the structure of a composition effectively and improve language forms at the same time [6].

\subsection{Reading-Writing Integration in Chinese EFL Education}

Based on a detailed comparison, teaching writing of EFL has many common places with that of Englishspeaking countries.

\subsubsection{Development of Reading-Writing Integration in China as EFL}

Compared with traditional approaches of teaching English writing in EFL, RWI pedagogy is thought to be younger and more immature in the Chinese EFL environment. Influenced by the Western educational reform, Chinese teaching practice on improving teaching English writing originated in the 1980s [1]. In order to discover what effects RWI pedagogy can have and which writing method has the most significant effect, it is better to first get a comprehensive knowledge of its history and background in China.
The practice of RWI teaching has been experimented on different grades of students in China. Many junior high school teachers carried out teaching writing through reading method into their classes and most of them found this method helpful in improving students' abilities to absorb knowledge and acquire linguistic skills [7]. In senior high school, some teachers applied constructivism into teaching writing through reading, aiming to enhance students' roles in class and train their sense of self-studying and critical thinking abilities [8]. Moreover, in colleges and universities, there are also many studies seeking methods to improve reading and writing for EFL learners. Some tried to combine mind maps with English reading and writing in college class. Using mind map as a new way to assist students to comprehend reading materials, scholars found it raising students' interests in reading [10]. Also, mind maps helped students understand the structures of the articles and they showed less linguistic errors in later writing after making mind maps. [11]

At the beginning of the 1990s, RWI pedagogy was originated by foreign scholars and began to be known by Chinese scholars. The Chinese researchers thus embarked on studying the relationship between English reading and writing. $\mathrm{Hu}$ Chundong was recognized as the first Chinese that propounded the idea of teaching English by synthesising linguistic skills. He put forward that the teaching of foreign language is integrative and the union of linguistic knowledge teaching and language skills cultivation could be realised by the practice of listening, speaking, reading and writing [20]. In the late 1990s, Liu Shangfu introduced "reading-discussingwriting" method in his work English Writing Theory. He pointed out the mutually encouraging relation between reading and writing. The text is the basis of composition practice and the original source of writing elements and expression approaches [21]. Yet Professor Liu did not introduce the specific operation instruction of "readingdiscussing-writing" teaching method, which left considerable rooms for future studies [22]. Up till the 21 st century, the teaching focus of EFL writing has shifted from "imitating composition after reading" to "equal-proportional reading-writing combination" and to "using comprehensive teaching of literacy skills", in order to improve writing skills.

Plenty of research have been done to examine the outcome of high school EFL on comprehensive teaching of literacy skills because some Chinese high schools have been using the English textbooks based on RWI concept for teaching, e.g. SEFC (2003 version) and NSEFC (2004 version) [22]. The development of Chinese EFL teaching has come along a way from "separately teaching" to "comprehensively teaching".

Apart from the high school teaching system, the college English major curriculum setting also plays an important role. In the late $1990 \mathrm{~s}$, the basic curriculum 
system of college English major has seen combined course names-- such as "comprehensive English, listening-speaking, visual-audio-oral, reading-writing"-gradually replacing the individual course names like "intensive reading, extensive reading, listening, speaking and writing" [22]. A trend could be seen from this phenomenon that more Chinese college teachers are adapting to comprehensive English teaching and are becoming aware of the efficiency of combining reading teaching with writing teaching. There have been many studies devoted to examining the relationship between reading and writing in EFL. However, further research is needed to examine what kind of effect reading and writing could bring to each other and to discover effective approaches of teaching EFL writing under the guide of RWI.

At the beginning stage of studying holistic readingwriting teaching methods, Chinese scholars had introduced and absorbed the essential parts of foreign educators' opinions. Some of them have dug deeper to examine the relationship between reading and writing, some have invented innovative ways of improving EFL learners' writing skills by comprehensive literacy teaching. For example, Flood, Indrisano, et al. have suggested that "both reading and writing contain the processes of composing and comprehending at the same time" [13][14], yet there is a paucity of study to examine whether reading achievement could improve writing performance or whether reading ability could enhance writing skills. Therefore, an empirical study was conducted by Chinese scholars. They designed a quantitative experiment, aiming to search out whether English novel reading would improve college EFL learners' English writing abilities and motivate their English learning. In conclusion, they used statistics to show that English novel reading had positive impact on the level of English writing proficiency and English learners' learning motivation [15].

Based on the constructivism, some Chinese scholars inclined to agree that model instruction is one of the best way to teach Chinese EFL writing for the reason that it inspired students' creativity, trained their writing skills and improved their thinking abilities [6]. Using not only works written by famous authors but also texts written by classmates as models to learn from, many scholars believed it would help students cultivate their sense of language and learn to express Chinese thoughts in English ways [16]. Xu Hao and Gao Caifeng conducted a two-year research on Chinese EFL college students to find that the RWI pedagogy had significant influence on writing ability and development of abstract thinking ability, but had slightly improvement on reading ability. The improvement of writing skills mainly focused on sentence fluency and grammatical complexity [17]. Many other Chinese scholars examined the writing behaviours of EFL college students after being taught by mind-map reading-writing method.
Results showed that mind-map teaching method seemed to help students better explain their thoughts and cultivate writing skills, and also decreased the amount of making Chinese sentences [18]. As the RWI pedagogy develops through time, a larger amount of English teachers in China gradually become aware of the significance of teaching their students understand how reading and writing work together and what benefits they could bring along. Some of the methods have been introduced and utilised in Chinese EFL teaching class. Nevertheless, there appeared to be some distinction between Chinese ways and English ways (especially in English-speaking countries) of teaching EFL writing. "Chinese EFL teaching should always be oriented by reading and writing", as College English Syllabus guided. Many of the researches conducted by Chinese scholars are targeted on junior and senior high school students, few studies have been done focused on college EFL writing curriculums. Despite many researchers predicted the RWI pedagogy might become the future of Chinese EFL writing teaching, the present studies around RWI method seemed to ignore the different language levels students had and research flaws caused by this. Therefore, a systematic and holistic RWI pedagogy which adapts to various language levels of students is expected to be found in the future.

\subsubsection{Current Situations of Reading-Writing Integration in Chinese EFL}

Although the total number of studies in this filed is small and some limitations remained, several experimental conclusions seem possible to draw.

First, traditional teaching mode of EFL writing in Chinese classrooms tends to transform writing instruction into linguistic learning, in which teachers are likely to set writing assignment and modify grammatical mistakes in sentences after students finish writing after class. It is worth noting that this kind of writing instruction has been a common but ineffective way of teaching. Among many empirical studies, Chinese scholars find that most Chinese college students appear to be weak in English writing, with poor statement, lack of coherency and fluency, low lexical complexity, errors in grammar and other obstacles [10]. It seems reasonable to deduce the reasons behind these phenomena: cultural otherness in Chinese and Western thinking patterns, different ways to express, students' insufficiency of lexical and grammatical knowledge [10], and paucity of relative training in writing. With more and more college English teachers raising awareness of the ineffective writing instruction, they become acceptive toward the RWI pedagogy, instead of teaching writing skills or reading skills alone. 
Second, those who seek to improve EFL writing ability through reading instruction may find the RWI pedagogy helpful. Though writing instruction may do little help to improve reading ability, writing reading journals seemed to benefit students in many aspects such as motivating their reading interests, broadening their minds, enriching vocabulary and enhancing grammatical complexity in their compositions[14].

Third, another fact worth noting is that in the correlational studies and experimental researches on examining the effects of RWI, the reading materials scholars have chosen are mostly expository or stimulating. Study results showed these kinds of reading materials could intrigue students' interests and cultivate their critical thinking abilities at the same time [6][15].

Forth, textbook reformation is another factor that comes along with the innovation of college English major course settings. Regarding the deepening reform of China's higher foreign language education, the cultivation of the ability to think is one of the most important issues. Since the 21 st century, foreign language education in colleges seems to have gone far from the development of thinking ability [25]. Modern English major textbooks, represented by the series textbook called Critical English Course, has made progress in cultivation of thinking abilities including the acquisition of language. The chief editor Sun Youzhong stated that the series were designed to not only help teachers and students acquire linguistic knowledge, but also make intercultural communications and critical thoughts possible during the course of language learning [25]. The RWI pedagogy is thought to be one of the most effective ways to cultivate people's critical thinking abilities while improving linguistic knowledge. With the help of the Critical English Course series, some English teachers from College of Foreign Languages (CFL) in Zhejiang University of Technology (ZJUT) start to shift their education focus from "teaching writing skills only" to "teaching students how to think and write".

\subsection{The Results of the Interview and Survey}

The author interviewed one of English teachers from ZJUT CFL mainly about her course design and opinions about Chinese EFL writing education and surveyed 21 students about their views about Ms Zhou's "English Reading and Writing". These 21 students were all sophomore students from Ms Zhou's class "English Reading and Writing”.

Before we started the interview, I first inquired about Ms Zhou's teaching experience in ZJUT. She has 13 years of teaching experience in English major after achieving the post-doctoral degree from University of Windsor. She has been teaching "English Reading and Writing" course for over 4 years.
At the beginning of the interview, Ms Zhou talked about the current issue in English writing class among Chinese students, which is that most compositions students write are not sufficient in content because they tend to pay more attention to avoiding grammatical mistakes. This reflects that nowadays, students seem to spend little time in real critically thinking. In order to develop students' habit of thinking, Ms Zhou creates a diversified strategy of her curriculum activities including brainstorming, debating, group discussing and free talking. She also emphasizes on cultivation of students' abilities to interculturally communicate and to internalize knowledges and cultures.

Ms Zhou sets her curriculum activity in the light of what Blanton's study had suggested [41]. The regular course routine begins with students self-reading an article written by a famous person in the textbook in class. Then led by the teacher, the whole class analyse the structure and main ideas of the article. After reading and analysing, there will be a short discussion based on the content within the group of four. After that, Ms Zhou would organise a brainstorming or a debate over the gist of the unit, which may last for about 20 minutes. The brainstorming or the debate aims to let nearly every student have a chance to convey their ideas and/or comment on other's opinions. The teacher' work is to write the main points on the blackboard and to synthesise elements of thoughts together after the activity is finished.

Ms Zhou expressed her initial intentions to organise curriculums in this way during our interview. In the reading session, she would focus more on the writing techniques and useful expressions in the article. By intensively reading on particular paragraphs, students highlight the useful expressions under teacher's guide. "By underlining and analyzing excellent sentences," Ms Zhou said, "I want to teach students how to imitate and utilize them in their own writing. Then eventually, I hope that they could learn to internalize these nice words into their minds and use them in their future work."

During the processes of analysing and commenting, Ms Zhou intends to teach students to talk more and to think deeper by reciprocally inspiring, and she would also pose several thought-provoking questions in the meantime. As a result, all of 21 students responded in our survey that these ways of designing the writing class and these activities in the classroom helped them think from various angles and they could benefit from these activities.

After the discussion and debating session, the teacher will give a theme and set a writing task for students to finish in class. After about 20-minute timelimited writing, students are going to peer review each other's work and recommend one or two pieces of work to be projected on the screen. The teacher will then give 
some short advice to the projected work and invite all students to give their peer reviews. This part is usually called "revision", similar to what Martinez called "Round Robin" practice [34]. During the revision stage, the teacher points out a few grammatical or expressive mistakes, then students could choose one or two of them and give their suggestions. With peer evaluation, Ms Zhou wanted students to acquire the ability to selfassess and to express accurately. A number of students later reviewed in the survey that by peer evaluation, they learnt to think more comprehensively and logically.

\section{CONCLUSION}

The essay discussed about how RWI developed through these years and how it grew in China EFL environment, especially in college education. Because RWI is considered as a way to teach writing mainly, I first examined on the development of Chinese EFL writing education background and history. As more foreign scholars began to seek diverse approaches to enhance the effectiveness of teaching English writing as L1 and L2, some of Chinese scholars also set out to do theoretical and empirical studies.

The research finds that Chinese writing education has made a great progress throughout the year. The reform of course setting is a significant signal. The core of syllabus has been moved to focus more on the cultivation of students' abilities to think critically, which has led the direction of textbook editing from simple instruction of writing skills to the combination of holistic aspects of language, including reading passages, answering comprehension questions and writing short reviews. The textbook reform cared about the comprehensive development of students' abilities to read, write and most importantly, to think globally and critically. Thus, teachers turned their education focus to developmental linguistic skill instruction as well as allround quality education. They paid more attention to organising curriculum activities in order to seize students' interests and gradually shifted their roles from being a lecturer who only gave speech and did not care if students listened to him or not to more like an inspirer who is good at catching teachable moments and appropriately mentors students.

As a sophomore English-major student of ZJUT, I view writing as a tool to communicate ideas and to absorb knowledge. However, the path of learning how to write in English accurately and authentically is difficult, especially for a non-native speaker. To be honest, I used to find simply learning writing skills in writing class is not as interesting as other English major lessons. I once had a one-semester English writing course in which the teacher only read after what was written on the textbook and seldom set any writing practice. Only 4 compositions were made by me when this 16-week semester ended, but I neither learnt how to write nor how to organise words from this lesson. I even found nearly no difference between my first writing and last one. Next semester, I chose Ms Zhou's English writing course. Based on the same textbook series, with different teaching methods, I was impressed by the first second in the class. The discussion topics were fascinating enough to let nearly everybody engage in the brainstorm discussion or the debate. Though the moments were intensive, I felt time going by quickly. Through one-semester learning, I achieved not only particular writing skills like hedging words and logical organisation, but also multiple thinking abilities such as considering thoroughly and building my mind-net. According to Ms Zhou, mind-net is a network which connects piece of our daily scattered thoughts together. When a writer wants to compose his opinions on something, he could first select some of his former thoughts from the mind-net then cohere them into the passage. The mind-net is one the most unforgettable knowledge I have learnt from Ms Zhou's writing class.

Although my essay included a certain quantity of studies done by many predecessors and all of the mentioned results had been presented positively, the reality existed a number of studies which did not find convincing results. Unfortunately, during my research on the relationship between reading instruction and writing skills, I found a small group of studies that did not show significant differences between their experimental group and control group. I personally respected all the work. The reason why I did not introduce them in my essay was that this essay was to discuss about the development of RWI pedagogy in the Chinese EFL environment and the relationship between reading and writing. Useful and positive results would do good to my research and support my opinion that in the future, the RWI pedagogy would become one of the most effective approaches to teach English writing as weel as reading.

Despite the limitation in my essay, I sincerely hope my interview and survey could reflect some positive sides of the RWI pedagogy and contribute to the reformation of Chinese EFL writing education in college.

\section{REFERENCES}

[1] Zeng Liuying, Li Li. A Review of Research on Integrated Teaching of English Reading and Writing in China and Abroad[J]. Foreign Language Teaching and Research. 2016: 81-82.

[2] Widdowson H G. Teaching Language As Communication[M]. Oxford University:1978.

[3] Swain.M.\& S. Lapkin. Problems in Output and the Cognitive Processes They Generate:A step towards second language learning[J]. Applied Linguistics. 1995. $16: 371-91$. 
[4] Stotsky, S. Research on Reading/Writing Relationships: A Synthesis and Suggested Directions[J].Language Arts,1983,60(5): 627-642.

[5] Xie Weina. On the Fusion of Reading and Writing[J]. Foreign Language Teaching. 1994: 5052.

[6] Chen Liping. The Model Essay Teaching in Writing Teaching Viewed from the Relationship between Reading and Writing[J]. Foreign Languages and Foreign Language Teaching. 2001(4):28-29,38.

[7] Wang Juan'e. The Combination of English Reading Teaching and Writing Teaching in Junior High School[J]. Journal of School of Foreign Languages. Shandong Normal University (Basic English Education), 2012, 14(2):61-65.

[8] Wu Chunxia. Student-oriented High School English Writing Teaching [J]. Journal of School of Foreign Languages. Shandong Normal University (Basic English Education), 2009(1): 44-47.

[9] Aaron David Mermelstein. Improving EFL Learners' Writing Through Enhanced Extensive Reading[J]. Reading in a Foreign Language. 2015(27):182-198.

[10] Zhang Haifeng. Research on English Major Writing Teaching Based on Mind Mapping[J]. China New Telecommunications. 2018,20(11):148149.

[11] Hu Yuting. Study on the Teaching Model of Reading to Promote Writing in College English Writing from the Perspective of Mind Map[J]. Campus English. 2017(7):3-4.

[12] Loban, W. The Language of Elementary School Children. (Research Report No. 1). Urbana, III: National Council of Teachers of English. 1963.

[13] Flood J, Lapp D. Reading and writing relationship: assumptions and directions $[\mathrm{J}]$. SquireJ R. The Dynamics of Language Learning. Urbana, III: ERIC Clearinghouse on Reading and Communication Skills and NCRE, 1987: 9-26.

[14] Indrisano R. Reading and Writing Revisited[M]. Ginn Occasional Paper. Lexington. Mass: Ginn and Co. 1984.

[15] Liu Zhicheng. An Empirical Study on the Influence of English Novel Reading on Non-English Major College Students' English Writing Ability and English Learning Motivation[J]. Journal of Yunnan University. 2020, 42(S1): 164-169.

[16] Chen Liping. The Model Essay Teaching in Writing Teaching Viewed from the Relationship between Reading and Writing $[\mathrm{J}]$. Foreign Languages and Foreign Language Teaching. 2001(4):28-29,38.

[17] Xu Hao, Gao Caifeng. An Experimental Research on the Teaching Model of Combination of Reading and Writing in the Lower Grades of English Majors[J]. Modern Foreign Languages. 2007: 184.

[18] Hu Yuting. Study on the Teaching Model of Reading to Promote Writing in College English Writing from the Perspective of Mind Maps[J]. Campus English. 2017(7):3-4.

[19] Tieney R J. Shanahan T.Research on the Readingwriting Relationship: Interactions, Transactions, and Outcomes [A].Barr R. Kamil M L , Mosenthal P, Pearson P D.(Eds.). Handbook of Reading Research [C]. NewYork: Longman, 1991, Vol. 2. 246-280.

[20] $\mathrm{Hu}$ Chundong. English Teaching Method[M].Beijing: Higher Education Publishing House, 1990.24-27.

[21] Liu Shangfu. English Writing Theory[M]. Nanning: Guangxi Education Publishing House, 1998.57-58.

[22] Mou Jinjiang. A Review of Comprehensive Teaching and Research on English Reading and Writing Skills in China and Abroad[J]. Curriculum. Teaching Material. Teaching Method. 2010(3):103-107.

[23] Mermelstein L. Reading/Writing Connections in the K-12 Classroom: Find the Clarity and Then Blur the Lines [M]. Pearson Education, 2006, Inc, i-iii, 1 .

[24] Sheng Yinying. Improving Reading through Writing and Combining Reading and Writing: an Experimental Study of English Writing Teaching[J]. Journal of Nanchang College of Education. 2005(2): 43-46.

[25] Sun Youzhong. Foreign Language Education and The Development of Thinking Ability. Chinese Foreign Languages, 2015 (3): 22-23.

[26] Koda, K. Reading and language learning: Crosslinguistic constraints on second language reading development. Language Learning, 2007 57(1), 144.

[27] Grabe, W. Reading and writing relations: Second language perspectives on research and practice. In B. Kroll (Ed.), Exploring the dynamics of second language writing. New York: Cambridge University Press. 2003: 242-262.

[28] Hedgcock, J., \& Atkinson, D. Differing readingwriting relationships in L1 and L2 literacy 
development? TESOL Quarterly. 1993. 27(2), 329333.

[29] Llach, M. D. P. A. Examining the role of L2 proficiency in L2 reading-writing relationships. Estudios Ingleses de la Universidad Complutense, 2010. 18, 35-52.

[30] Zhang Jisheng, Zhou Ping. A Comparative Study of the "Product Approaches" and the "Process Approaches" in Teaching English Writing[J]. Foreign Languages and Their Teaching. 2002(9): 19-22.

[31] Nunan, D. Language Teaching Methodology[M]. Prentice hall.1991.

[32] Vivian Zamel. The Composing Processes of Advanced ESL Students: Six Cases Studies[J]. TESOL Quaterly. 1983(17): 165-187.

[33] Raimes, A. Techniques in Teaching Writing, OUP.1983.

[34] Martinez, N. Martinez, J. Basic College Writing[M]. Prentice Hall. 1991.

[35] Wang Chuming. A Study of the Interrelationship Between L2 Learning Variables and L2 Use[J]. Foreign Languages in China. 2009(9): 53-59.

[36] Vygotsky, L. S. Thought and Language [M]. Cambridge, MA: Harvard, 1962.

[37] Jihye Choi et al. Examining the Relationship between Reading and Writing of Advanced Korean EFL Learners[J]. Korean Journal of Applied Linguistics. 2018: 91-116.

[38] Lazdowski. W. Determining Reading Grade Levels from Analysis of Written Compositions. Doctoral dissertation. New Mexico State University. 1976.

[39] Mills. E. Children's Literature and Teaching Written Composition. Elementary English. 1974.

[40] Bossone. R, Quitman L. A. A Strategy for Coping With High School and College Remedial English Problems. 1976.

[41] Blanton L. L. A Holistic Approach to College ESL: Integrating Language and Content[J]. ELT Journal. 1992. 